\title{
Implementation of Forest Policy in Greece in Relation to Biodiversity and Climate Change
}

\section{Konstantinos Spanos ${ }^{1 *}$, Dionysios Gaitanis ${ }^{1}$, Asimina Skouteri ${ }^{2}$, Panos Petrakis ${ }^{2}$, Ioannis Meliadis ${ }^{1}$}

\author{
${ }^{1}$ Hellenic Agricultural Organization, General Directorate of Agricultural Research, Forest Research Institute, \\ Thessaloniki, Greece \\ ${ }^{2}$ Hellenic Agricultural Organization, General Directorate of Agricultural Research, Institute of Mediterranean Forest Ecosystems, \\ Athens, Greece \\ Email: *kspanos@fri.gr
}

How to cite this paper: Spanos, K., Gaitanis, D., Skouteri, A., Petrakis, P. and Meliadis, I. (2018) Implementation of Forest Policy in Greece in Relation to Biodiversity and Climate Change. Open Journal of Ecology, 8, 174-191.

https://doi.org/10.4236/oje.2018.83012

Received: November 21, 2017

Accepted: March 25, 2018

Published: March 28, 2018

Copyright (C) 2018 by authors and Scientific Research Publishing Inc. This work is licensed under the Creative Commons Attribution International License (CC BY 4.0).

http://creativecommons.org/licenses/by/4.0/

\section{Open Access}

\begin{abstract}
This is a review article based on literature (national and international) and empirical approach. A general overview on research priority areas on biodiversity and approaches and tools to provide information for forest policy implementation on biodiversity are briefly summarized. Challenges for biodiversity research and related policy in Europe and Greece are depicted. General information on forests, protected areas and forest management in Greece is also presented. Major actions and measures for conservation of forest biodiversity in Greece are described and analysed. The implementation of forest policy in Greece (including the adoption of International constitutional frame) in relation to biodiversity protection and climate change is also analysed. Priorities identified by the Strategic Plan of Rural Development 2007-2013 in Greece in order to adapt to climate change, are also presented. Furthermore, the National institutional framework (Legislation) and strategic targets for biodiversity conservation in Greece are synoptically presented. Finally, major conclusions and future challenges are highlighted.
\end{abstract}

\section{Keywords}

Biodiversity, Conservation, Protected Areas, Forest Policy, Implementation, Strategic Targets

\section{Introduction}

The definition of Biodiversity has set as follows: Biodiversity is composed of the total biological variation, ranging from within-species genetic variation, through species, communities, and landscapes [1]. The international community is in- 
creasingly aware of the link between biodiversity and sustainable development. More and more people realize that the variety of all life forms on earth, the ecosystems and their functions form the basis for our economy, health and well-being [2] [3]. In the Nagoya Protocol (2010) the international community made a commitment to future generations and adopted the Strategic Plan for Biodiversity 2011-2020 and 20 Aichi Biodiversity Targets. At that time there was recognition that biodiversity was not a problem, but essential for sustainable development, and the foundation for human well-being. Four years later, Global Biodiversity Outlook 4 provided an important measure of how this issue is progressing [2]. The priority research themes, identified (by the Nagoya Protocol) through the analysis of key international and European biodiversity research strategies as well as environmental policy documents, are the following [4] [5] [6] [7] [8]:

- Ecosystem services related to biodiversity,

- Understanding and adapting to changes,

- Conservation and management of biodiversity,

- Sustainable use of biodiversity: agriculture, fisheries and forestry,

- Understanding the underlying causes of biodiversity loss.

These research priority areas aim to better understand and predict changes at all levels of biodiversity (from genes to species and then to ecosystems) and to investigate the potential consequences of these changes on human life. However, current international and European research strategies clearly highlight that these priorities cannot be managed properly without a strong knowledge developed by evaluating and monitoring biodiversity at all scales (genes, species, ecosystems-using molecular techniques and biodiversity indicators) and a deeper understanding of the relations between biodiversity, ecosystem functioning (e.g. clean water) and the services (e.g. recreation) provided to humans [4] [6] [9]. A strong focus is placed on exploring underlying causes of biodiversity loss (e.g. using biodiversity indices see [10]). Direct drivers of change such as pollution (particularly nitrogen), habitat fragmentation and degradation, invasive species or overexploitation of natural sources are clearly linked to our current life style and unsustainable economy. At the same time a strong emphasis is put on investigating how humans and societies depend on biodiversity through research on ecosystem functions and services. Research on conservation and management for the sustainable use of natural resources will also be critical to address the major questions related to landscape and forest management in the face of growing pressure for multiple uses [3] [5]. These areas of research will build on knowledge of biodiversity changes and losses (e.g. total species, keystone species, rare species, indicator species) and associated ecosystem services [10] [11]. They also require extensive investigation of adaptive management, as well as research on new and innovative conservation and restoration policies.

Forest policy in Europe is very diverse and has to do with the many different topics of forestry and the legislation status in each EU country. Forest policies 
require a broad perspective on land use and natural resource management including biodiversity. Forest policy needs to be updated on a regular basis and the involvement of stakeholders plays an important role in this process, often through workshops, targeted meetings and interviews [6] [12]. A broad variety of approaches and tools exist to support policy-makers in their consideration of different future scenarios and possible responses in relation to biodiversity. Many of these allow the involvement of stakeholders and policy makers, supported by information technology. However, the choice, the availability and the applicability of software tools are not always clear and comprehensive. In effect, participatory scenario development, with a focus on future perspectives on forests and their management, is often not prepared when countries implement their national forest policies. There are several methods and tools available for stakeholder involvement and future-oriented policy-making on biodiversity issues [6] [12] [13]. The tools are diverse and focus on several policy topics all related to biodiversity management and conservation (Table 1).

Models and tools may compare different policies, land uses or management options. They can provide information, promote stakeholder interaction, link forest issues with broader social aspects and compare future scenarios. As no single available model meets all these requirements, a combination of different methods and tools is necessary [6] [14]. It is important, to present the results of the developed models in assessing and monitoring of biodiversity to people in a

Table 1. Forest policy topics related to biodiversity management and conservation.

\begin{tabular}{|c|c|}
\hline \multicolumn{2}{|c|}{ Forest policy topics related to biodiversity management and conservation } \\
\hline 1 & Natural Resources \\
\hline 2 & Ecosystem Services \\
\hline 3 & Forest Inventory and Land Use Mapping \\
\hline 4 & Forest Certification and Wood Trade \\
\hline 5 & Forest Reproductive Material (certification and trade) \\
\hline 6 & Sustainable Forest Management \\
\hline 7 & Soil and Water Conservation \\
\hline 8 & Conservation of Forest Genetic Resources \\
\hline 9 & National Parks and other Protected Areas \\
\hline 10 & Biodiversity conservation and Protection of Habitats \\
\hline 11 & Forest Protection (woodlands) \\
\hline 12 & Biomass and Bioenergy and Impacts on Ecosystems \\
\hline 13 & Climate Change and Mitigation \\
\hline 14 & Climate Change and Adaptive Forest Management \\
\hline 15 & Land Use and Landscape Conservation \\
\hline 16 & Environmental Pollution (air, soil \& water) \\
\hline 17 & Urban and Sub-Urban Forestry \\
\hline 18 & Social Aspects \\
\hline
\end{tabular}


clear manner. Highly complex models (e.g. complicated models predicting future changes in biodiversity) have only limited value as a tool to stimulate participation, and may discourage active stakeholder participation in the policy implementation. The biggest challenge is to keep the models as simple as possible (e.g. development of simple indices) [9] [10] [11] [15] [16]. These models can help stakeholders better understand the complexities e.g. landscape dynamics or biodiversity changes and support better-informed decision-making and natural resource management [6] [9] [15] [16] [17].

The present study is a review work summarizing the challenges for biodiversity research and related policy in Europe and Greece but the focus is on the implementation of forest policy in Greece in relation to forest biodiversity, protection of forests and climate change.

\section{Challenges for Biodiversity Research and Related Policy in Europe and Greece}

As mentioned above, biodiversity is composed of the total biological variation, ranging from within-species genetic variation, through species, communities, and landscapes [1]. An understanding what biodiversity is and what ecosystem services are, considered highly important for any biodiversity study [1] [11] [18]. In 2010, the international year of biodiversity, new policies for preserving biodiversity in Europe and Worldwide were developed as targets set based on previous policies and forums, such as to halt biodiversity loss (e.g. reduction of total species, keystone species, rare species, and indicator species-measured using biodiversity indices) in the EU by 2010 . However, there is a need to set new priorities for new biodiversity policies [4] [6] [17] [19] [20]. Three key observations emphasize the urgency of an effective biodiversity conservation policy: 1) the alarming global decline and losses in biodiversity due to pollution (air, soil, water) and other human activities (e.g. deforestation); 2) the associated impacts on ecosystem services that are highly important to human life; 3 ) the complex of pollution, climate change and biodiversity loss. There are also important gaps in the processes regulating biodiversity and the relationship of biodiversity to ecosystem services. Filling the knowledge gaps is crucial to develop an efficient and sustainable policy on biodiversity conservation.

The biodiversity research challenges are broadly grouped into the following areas [4] [6] [19] [20]: 1) A first area focuses on different challenges coming out from documenting, monitoring and measuring biodiversity. 2) Important research topics on drivers of biodiversity, that need more attention, are related to: a) understand the processes of the community; b) large and complex ecosystems; c) landscape and meta-population structure; d) eco-evolutionary dynamics; e) species networks and identifying the keystone species; and f) issues associated with complex dynamics. 3) The challenges of linking biodiversity, functional diversity, and ecosystem services also highlights the need to study ecosystem services at landscape level and to investigate the economics of biodiversity and 
ecosystem services [6] [19] [20]. 4) Another important area of research direction is on understanding how species respond to anthropogenic impacts (e.g. [16] [17]) and also how species respond to conservation measures.

Effective biodiversity conservation strategies-in which policy makers, researchers, other stakeholders and the general public are involved-are summarized as follows [4] [6] [15] [17] [19] [20]:

1) It is necessary to invest in a European infrastructure for biodiversity data and research. It is important for Europe to invest in selected infrastructures which support biodiversity research in order to increase the knowledge on biodiversity and its impact on the functioning of ecosystems, and therefore help decision makers in implementing cost-effective management plans.

2) There is a need for a powerful plan enhancing fundamental knowledge of biodiversity drivers and threats.

3) There is a great need for an effective transfer of scientific knowledge into biodiversity practice to secure that scientific evidence is available to inform both, policy development and practical implementation of conservation management.

4) There is a need for a consistent and global biodiversity conservation policy, which also aims to change the behavior of people in Europe to ensure that biodiversity conservation in Europe and globally is highly important. We can mention here the Intergovernmental Platform on Biodiversity and Ecosystem Services (IPBES) which serves as an interface between the scientific community and policy makers with the aim to strengthen the use of science in policy making. The Platform was established in April 2012 and is an independent intergovernmental body that is open to all member countries of the United Nations. IPBES was officially opened in the UN Campus Bonn in July 2014 [18].

5) Given that biodiversity and ecosystem services (products and functions) are of huge importance for sustainable development in the long term, biodiversity issues in all national policies should be implemented. Per the 2006 Millennium Ecosystem Assessment (MA), ecosystem services are "the benefits people obtain from ecosystems". The MA also delineated the four categories of ecosystem services: supporting, provisioning, regulating and cultural [18].

6) When future biodiversity conservation strategies are developed, it is important to consider pollution, climate change impacts and sustainable development.

7) The economic consequences of biodiversity losses need to be quantified to enable a system in which the responsible person/company causing the loss will need to pay for the costs linked to the loss and the restoration of biodiversity. Here it becomes clear; in order to relate biodiversity loss to economic loss it has to be measured [11].

8) To realise efficient prevention, a European strategy to deal with invasive exotic species is of high priority. Prevention is the most efficient strategy to reduce the number of invasive exotic species and their negative impacts on biodiversity and natural environment. 
9) It is also important that the collaboration across scientific disciplines for integrated biodiversity research which therefore emphasizes the need to support multidisciplinary collaborative networks and Research and Technology Development (RTD) programmes.

10) Efforts for raising biodiversity education and awareness are necessary to get the support from the whole of society for a successful biodiversity policy implementation. Furthermore, the study of biodiversity and the ecological responses to environmental changes is of high priority.

To summarise, conservation measures and strategy for protecting biodiversity in Europe are highly important issues. Global climate change and pollution may cause change in the present distribution of important species (e.g. beech) in Europe (e.g. movement upwards to higher altitudes) and replacing parts of the beech forest area by other species (e.g. oak, fir, pine) [21]. However, the following evolutionary forces should be considered when sustainable forest management and adaptive silviculture are applied in order to face climate change [17] [22]: 1) Evolutionary dynamics, 2) Population size, 3) Threats to a population or the species, 4) Sustainable silviculture, and 5) Conservation of forest genetic resources.

\section{Forests and Forest Biodiversity in Greece}

In Greece, most of the forests and forested lands are State owned (>75\%). Of the total forests and forested lands around $20 \%$ are high forests, mostly naturally regenerated. The rest are partly forested areas, bush lands, grazing lands, rocky areas or bare land [23]. Clearcuts and coppicing are mostly applied in non-state forest lands (municipal, church owned, private persons). The coppiced forests-averaging $48 \%-50 \%$ of the total forests-are still managed by this system, but recently there has been political and societal pressure to partly convert these forests into seedling ones. The average growing stock is estimated to be $62 \mathrm{~m}^{3} / \mathrm{ha}$ and around $70 \%$ of the harvested wood is used as firewood. A large part $(\approx 60 \%)$ of the forests and forested lands have been included in the NATURA 2000 network [23] [24]. Forest biodiversity in Greece is one of the richest (e.g. species richness and biodiversity quality) in Europe (Figure 1). This is partly due to the influence of diverse climate and micro-climatic types varying from semi-arid type of Southeastern Crete to cold wet continental type in North-Western Greece, and the relatively slight (until recently) human activities.

Forests in Greece have been managed sustainably over a long period of time until now [22] [23] [25]. Their importance as biodiversity components has been widely recognized. There is a strong legal protection status for all forested areas and special efforts have been made in recent years for the identification and conservation of their biodiversity values (quality). They are also an essential resource for local communities in terms of both wood (e.g. timber, firewood) and non-wood products (e.g. fruits and seeds, mushrooms, snails, medicines, herbal plants, recreation, hunting, grazing, resin, honey) [26] [27]. 

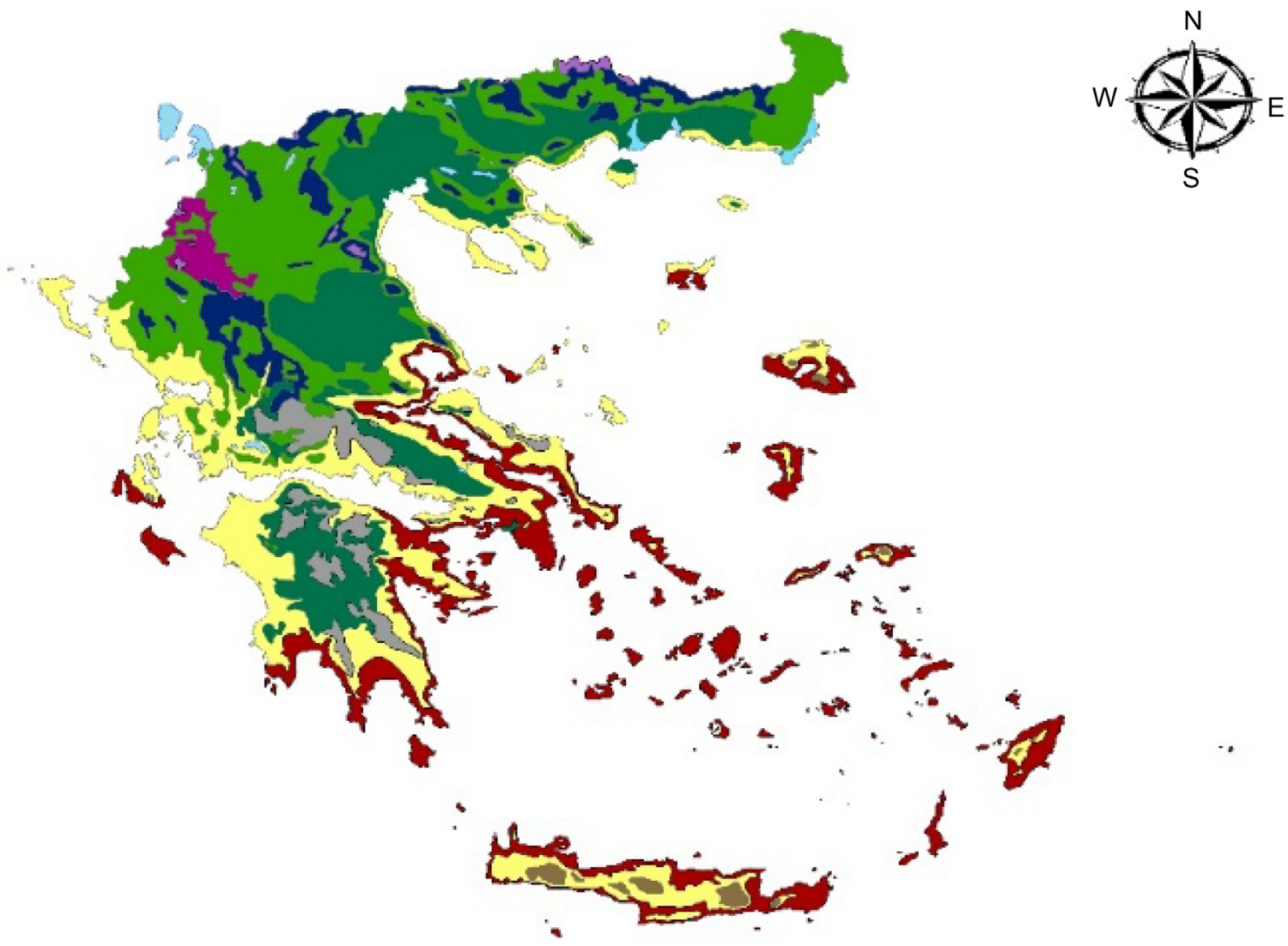

Legend

Oleo - Ceratonion (charact. species: Olea

europea var sylvesrtjs, Ceratonia siliqua,

various spiny bushes, Pistacia lentiscus,

Quercus coccifera, Erica spp., Myrtus

communis, Pinus halepensis, etc.)

Quercion ilicis (charact. species: Quercus ilex

Quercus coccifera, Fraxinus ornus. Arbutus spp.

Erica spp., Phillyrea latifolia, Quercus pubescens,

Pinus halepensis. P. brutia, etc.)

Cupression - Cocciferae (charact. species: Cupressus sempervirens, Quercus coccifera, etc.)

Ostryo - Carpinion (charact. spaces: Ostrya carpinifolia,

Carpinus orientalis, Quercus coccifera, Quercus

pubescens, Fraxinus ornus, Sorbus spp.,

Ulmus spp., Acer spp., etc.)

Abietion cephatonicae (charact. species: Abies cephalonica, Pinus nigra var. palasiana, Quercus coccifera, etc.)

Pinetalia nigrae (charact. species: Pinus nigra var. austriaca, etc.)

Vacinio - Picetalia (charact. species: Picea abies, Pinus sylvestris, P. heldreichii, Betula pendula, etc.)

Azonal - riparian vegetation (tree species: Populus spp.

Platanus orientalis, Alnus glutinosa,

Fraxinus angustifolia, Ulmus spp. etc.)

Quercion confertae (charact species Quercus conferta,

Quercus petraea, Sorbus spp., Tilia spp., Acer spp.,

Ostrya carpinifolia, Castanea vera. Fraxinus ornus,

Quercus cerris, etc.)

Fagion moesiacae (charact. species. Fagus orientalis,

Fagus sylvatica, Abies borissi regis, etc.)

Lakes

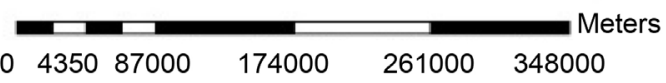

Figure 1. Map of forest vegetation zones (extant or potential) of Greece.

Also highly important is the functional role of the forest ecosystems. The main ecosystem functions have been recognised as the following: soil conservation, 
water balance, carbon sequestration, wild life maintenance, climate change mitigation, and biodiversity support. The number of plant taxa (species and subspecies) of the very rich flora in Greece is estimated to 6500 (5750 species); $15.1 \%$ $17.6 \%$ at species and $17.7 \%-20.9 \%$ at taxa level are endemic [28]. More than 50,000 animal species (there are already 15,000 are known out of which about $25 \%$ are endemic), more than 2000 species of fungi and 25 groups of habitat types (according to the CORINE classification and Directive 92/43/of the European Union).

However, Greece, as part of the Mediterranean Basin, is considered to be among the most vulnerable countries due to the combined effect of high temperatures and reduced precipitation in areas already coping with water scarcity [29] [30] [31]. Furthermore, land use changes and land use conflicts make this problem more complex. It is therefore quite urgent to adapt forest management to the changing climate in order to enable the conservation of healthy, productive forests, which provide people with goods and services. Integrating climate change into forest management requires an understanding of ecological response and the vulnerability of key tree species and forest ecosystems. Although a clear view of the future climate and forests is not yet available, it is critical to begin developing and implementing adaptation strategies now, well in advance of climate change impacts on the forests. Thus, it is crucial to adopt new silvicultural systems (e.g. convert coppiced stands into high forests to increase seed production) in order to mitigate climate change and conserve, utilize as much as possible genetic diversity and enhance in situ conservation (particularly of mature and overmature forests). It is well known, that genetics/genetic diversity is a dynamic biological process and therefore it is not possible to maintain the whole of it [19]. Losses will be inevitably occurring during the time but it is important and profitable to maintain high effective population numbers for the keystone species in order to conserve a rich biodiversity (high biodiversity quality) [4] [19] [32].

Since Greece started creating protected areas, administration has been carried out by the Forest Service-through its Forest District Offices-governmental bodies under the Ministry of Agriculture (now under the Ministry of Environment and Climatic Change). Decisions are made centrally and management practices include strict protection. Management decisions were made without any kind of anticipated participatory procedure. Although Law 1650/1986 granted more power to Ministry of Environment, Planning and Public Works, which is the main operator of forest policy development in the protected areas created after 1986, the actual management of all protected areas, created before 1986, still remains within Forest District Offices. Currently, 28 protected areas with Management Bodies were designated (Law 3044/2002) [30] [31]. The implementation of the Habitat Directive in 1992 was a turning point in national forest policy followed by changes in administration, in the statutory role of conservation authorities, new funding possibilities and broader involvement in decision-making and for- 
est policy. The creation of Natura 2000 framework serves multi-purpose objectives under the frame of sustainable forest management in the designated sites [23] [24].

\section{Implementation of Forest Policy in Relation to Biodiversity and Climate Change in Greece}

\section{International Conventions Frame for Biodiversity}

The International conventions ratified by the Greek State and related to Biodiversity (Table 2) have to do with the adoption of the international goals and the implementation of a definite framework of protection and reduction of Biodiversity losses at national level. Of particular importance are important areas for the Nature and Biodiversity such as (http://www.ypeka.gr, 2015):

1) The wetlands of International Importance of the Ramsar Convention (Figure 2).

2) The Monuments of the World Inheritance (UNESCO).

3) The Biosphere Reserves (UNESCO, Human and Biosphere).

4) The Special Protected Areas (Convention of Barcelona).

Table 2. International conventions ratified by the Hellenic State regarding biodiversity.

\begin{tabular}{|c|c|c|c|}
\hline Convention & Subject/Theme & $\begin{array}{c}\text { Place and Date of } \\
\text { Ratification }\end{array}$ & $\begin{array}{c}\text { Ratification in } \\
\text { Greece }\end{array}$ \\
\hline $\begin{array}{c}\text { Convention of } \\
\text { CITES }\end{array}$ & $\begin{array}{l}\text { Convention for the } \\
\text { international trade of } \\
\text { wild fauna and flora } \\
\text { threatened by } \\
\text { distinction }\end{array}$ & $\begin{array}{c}\text { Washington (USA) } \\
03 / 03 / 1973\end{array}$ & $\begin{array}{c}\text { Law } 2055 / 1992 \\
\text { (ФEK A'105/30-6-92) }\end{array}$ \\
\hline Convention of Bonn & $\begin{array}{c}\text { Convention for the } \\
\text { protection of } \\
\text { migrated birds }\end{array}$ & $\begin{array}{c}\text { Bonn (Germany) } \\
23 / 06 / 1979\end{array}$ & $\begin{array}{l}\text { N. 2719/1999 (ФEK } \\
\text { A' 106/26-05-1999) }\end{array}$ \\
\hline Convention of Bern & $\begin{array}{l}\text { Conservation for the } \\
\text { wild life and natural } \\
\text { environment of } \\
\text { Europe }\end{array}$ & $\begin{array}{c}\text { Bern (Switzerland) } \\
19 / 09 / 1979\end{array}$ & $\begin{array}{l}\text { N. } 1335 / 1983 \text { (ФЕК } \\
\text { A'32/14-03-1983) }\end{array}$ \\
\hline $\begin{array}{l}\text { Convention for } \\
\text { Biological Diversity }\end{array}$ & $\begin{array}{l}\text { Convention of the } \\
\text { United Nations for } \\
\text { the biological } \\
\text { diversity }\end{array}$ & $\begin{array}{c}\text { Rio de Janeiro } \\
\text { (Brazil) 05/06/1992 }\end{array}$ & $\begin{array}{l}\text { N. 2204/1994 (ФЕК } \\
\text { A' 59/15-04-1994). }\end{array}$ \\
\hline $\begin{array}{c}\text { The Protocol of } \\
\text { Carthagene }\end{array}$ & $\begin{array}{l}\text { Protocol for } \\
\text { biosecurity of the } \\
\text { United Nations' } \\
\text { Convention for the } \\
\text { biological diversity }\end{array}$ & $\begin{array}{c}\text { Nairobi (Kenya) } \\
24 / 05 / 2000\end{array}$ & 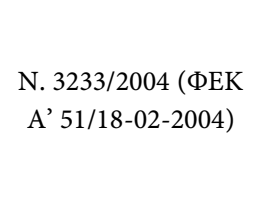 \\
\hline $\begin{array}{l}\text { The European } \\
\text { Convention of } \\
\text { Landscape }\end{array}$ & $\begin{array}{c}\text { Conservation of } \\
\text { European Landscapes }\end{array}$ & $\begin{array}{c}\text { Florence (Italy) } \\
20 / 10 / 2000\end{array}$ & $\begin{array}{l}\text { N. 3827/2010 (ФЕК } \\
\text { A'30/25-02-2010) }\end{array}$ \\
\hline
\end{tabular}

*Source: http://www.ypeka.gr (2015). 


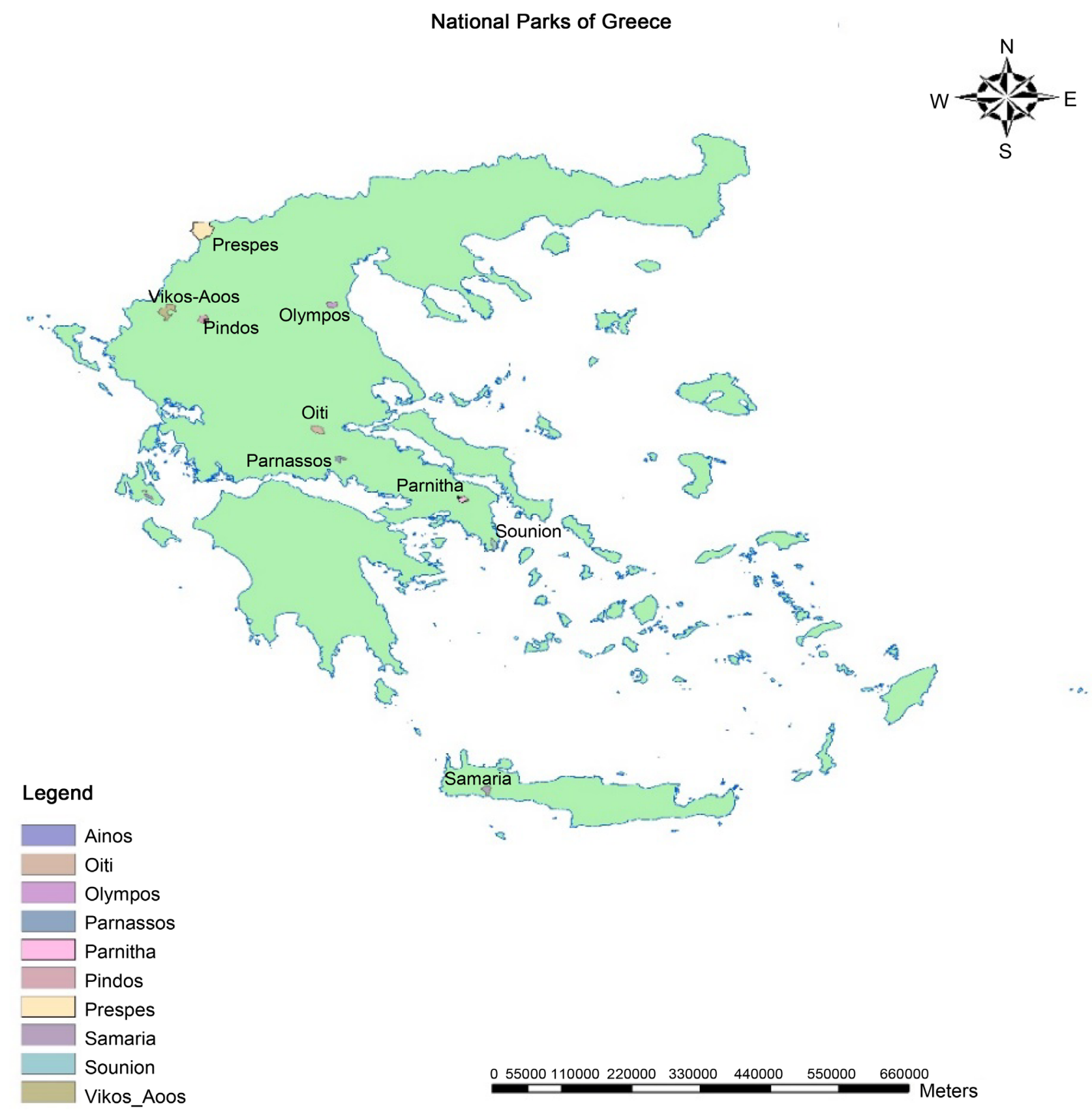

Figure 2. National parks of Greece.

5) The Biogenetic Reserves (Council of Europe).

6) The Areas that have been awarded the Euro diploma (Council of Europe).

Historical analysis of forest policy in Greece in relation to biodiversity is synoptically described as following:

1) Moving towards to the creation of the first National parks: $1938-1966$

The Law 856/37-generally defines national parks as "mainly forested areas of special conservation interest in terms of flora and fauna, geomorphology, soil, atmosphere, waters and general their natural environment for aesthetic, recreation and for carrying out all kinds of scientific research". As a start, seven (7) national 
parks were thus created in Greece [19] [26] (Figure 2).

2) The broadening of the protected areas: 1966-1992

Law 996/1971-primary purpose is conservation where recreational activities are only allowed if conservation values are not compromised [30] [31]. Fifteen (15) National parks were designated and most of them were located on mountainous areas. Designation of 19 aesthetic forests (total area of 32,506 ha) whose the main purpose was to give an opportunity to the public to learn and enjoy the natural environment and develop recreational activities. Declaration of 51 protected natural monuments (e.g. protection of special trees, geological formations and heritage protection) of a total area 16,840 ha. All the above categories of protected areas are on state land (state is the largest landowner in Greece, 75\%).

The International Ramsar convention was ratified by the Law 191/74-Greece has designated 11 regions as Wetlands of International Importance according to this Convention (Figure 3). The Ramsar Wetlands cover a total area of 167,300 ha. The total area of wetlands in Greece is estimated to 202,620 ha [33].

Law 1650/1986 replaces all previous legislation introducing changes regarding in situ demarcation procedure and 5 new categories of protected areas. Its implementation has been limited ( 2 marine parks were created in 1986 and no other areas were given special protection until 1992).

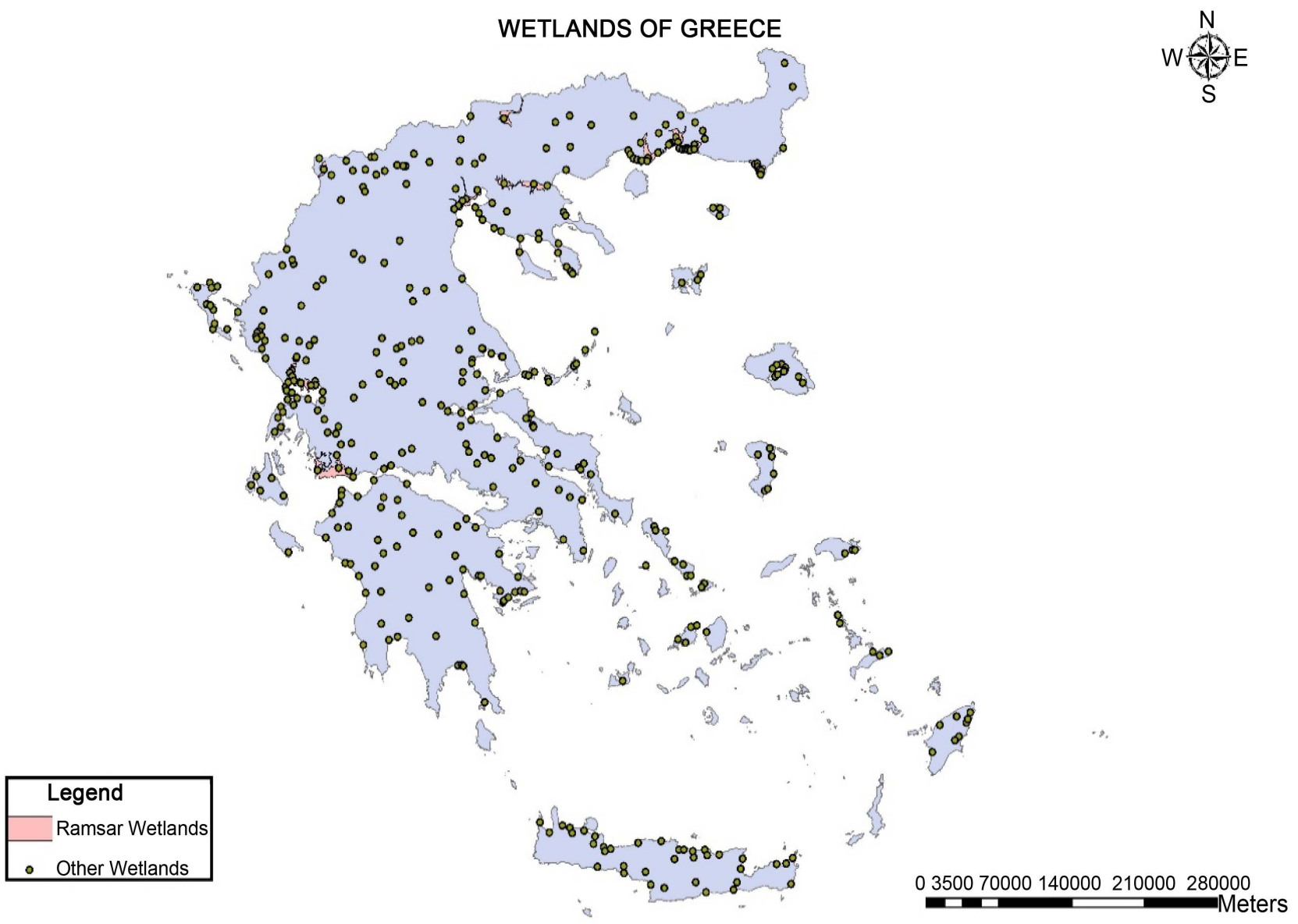

Figure 3. Map showing the wetlands of Greece. $\mathrm{R}=$ the Ramsar wetlands (source: http://www.ekby.gr/ekby/en/EKBY_Publications_en.html). 
3) Natura network: 1992 onwards

The implementation of this network in Greece was facilitated in the form of new laws and a declaration policy. Natura 2000 network is well representative in regards to the country's biodiversity and it distributed over the whole country [23] [30] (Figure 4). An initial list of 296 sites was identified in Greece (biodiversity and other relevant information was collected). Later, Greece has included

\section{Natura (2000) areas (including SCI and SPA) \\ in Greece}

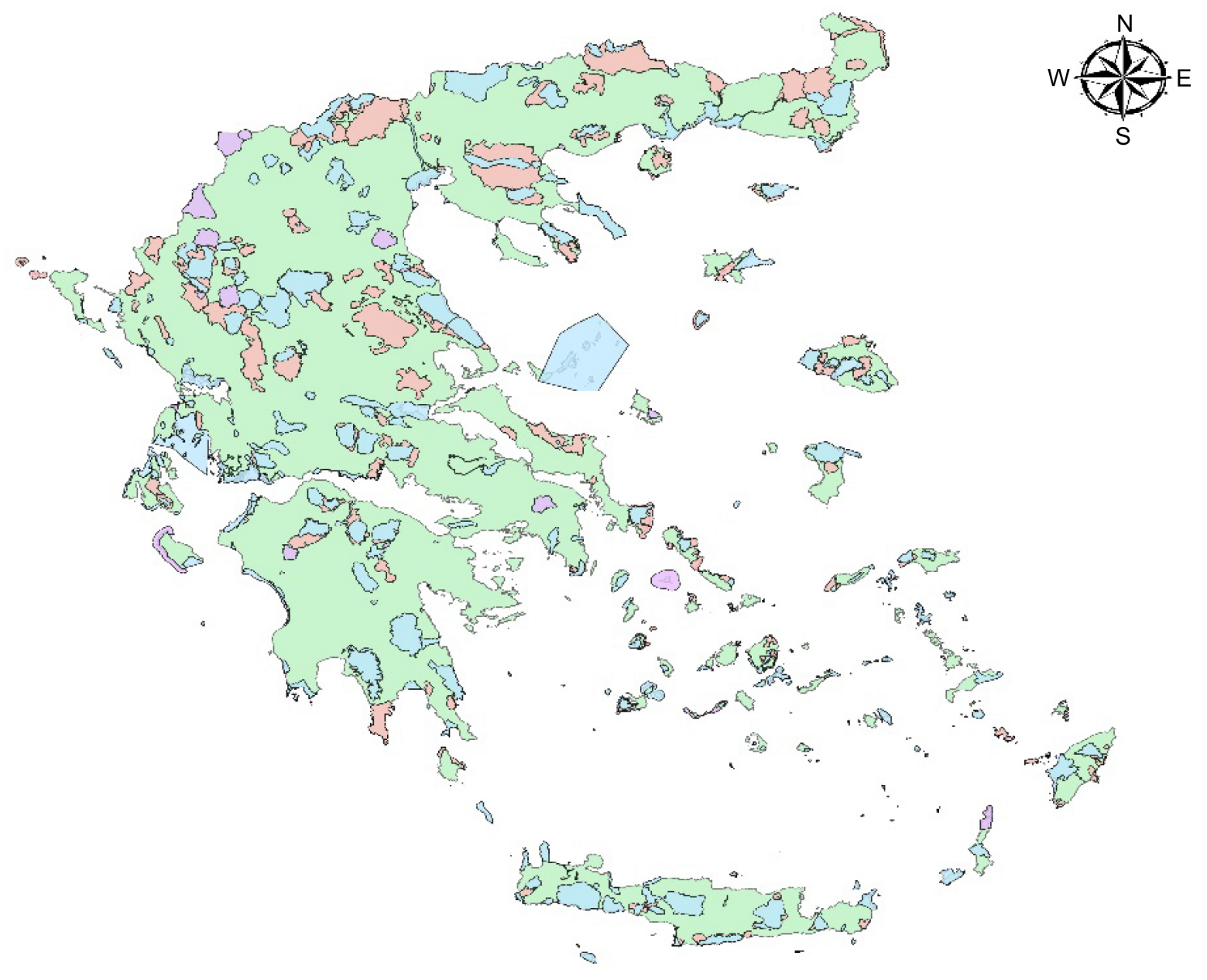

Legeng

$\mathrm{SCI}$ (Sites of Community Importance)

SPA (Special Protected Areas)

SPA SCI (SPA \& SCI)

\begin{tabular}{lllll}
0 & 4850097000 & 194000 & 291000 & 388000 \\
\hline
\end{tabular}

Figure 4. NATURA (2000) areas (including SCI \& SPA areas) designated in Greece. 
in the National list 241 Sites of Community Importance (SCI) according to the EU Directive 92/43 and has also declared 202 Special Protected Areas (SPA) according to EU Directive 79/409 (total area of 5.5 million ha) [30] [31].

Climate change mitigation and adaption is one of the main targets identified in the strategy for sustainable development launched by Ministry of Environment, Energy and Climate Change (MEECC) in 2002. Greece ratified the Kyoto Protocol in 2002 (Law 3017/2002) and adopted a National Programme ensuring its commitment by a decision of the Council of Ministers (DCM5/2003). By the Law 3017/2002, the former Ministry for the Environment, Physical Planning and Public Works (MEPPPW) - now MEECC—is designated as the governmental body responsible for the coordination of all other competent ministries and possibly any other public and/or private entities, for a) the implementation of the provisions of the Kyoto Protocol, and b) the formulation and monitoring of the National Programme for achieving the national targets set under the Kyoto Protocol [30] [31].

4) The strategic plan of rural development

The Strategic Plan of Rural Development 2007-2013 identified the priorities of Greece for the period 2007-2013. The National Strategy was implemented by the Program of Rural Development 2007-2013 (Hellenic Ministry of Rural Development and Food, November 2007), whose priorities are set in order to adapt to climate change. These priorities-related to forest sector-were: a) Operation of the System for the protection of forests from fires and other natural hazards, control of harmful pests and diseases that will affect forests and their productivity. It should be pointed out that the impacts of climate change push the forest ecosystems to higher altitudes and/or being replaced by others, b) Development of an information system regarding forests. Some important actions regarding adaptation to climate change have included [30] [31]:

- Construction of fire-preventing roads in forests where access to fire fighting means is not possible due to the lack of appropriate road systems. Construction of new roads and pathways in order to improve the forest road network.

- Construction of water supply centers (water tanks, etc.) and the indispensable works to improve the network of water provision for fire suppression.

- Removing/reducing dry biomass close to the ground or along forest roads and other regions of high fire risk.

- Tending, thinning and pruning works in coniferous forests in order to remove part of the flammable biomass.

- Construction and improvement of permanent forest fire surveillance systems. In addition to the measures above, actions have been taken in order to increase and restore forest areas [30] [31]:

- Reforestation plans (using native species and local provenances) for the restoration of fire destroyed forest areas.

- Logging and removal of burnt trees (removal is not recommended in steep slopes-e.g. $>30 \%)$

- Restoration works (reforestation, soil erosion prevention, etc.) and planting 
of less flammable species (e.g. Cupressus sempervirens and Pinus pinea replacing $P$. halepensis or P. brutia, various native broadleaves).

- Soil erosion preventive works in small erosion gullies using wood, stone, concrete, wire, etc.

- Watershed management in order to minimize soil degradation and maximize water storing and construction of small dams for collection of rain water.

- Drainage works to prevent landslides in sensitive geological substrata (e.g. Pindos mt, N. Evia).

Furthermore, in the context of the First Afforestation of Agricultural and Non-Agricultural Soils, 36,612 ha had to be afforested in the period 2004-2012 [30] [31]. Also, in the Program of Rural Development 2007-2013, actions concerning the reduction of coppice forests and conversion into high forests and the increase, renewal, improvement, replacement and enhancement of stoking volume (standing wood volume $-\mathrm{m}^{3} / \mathrm{ha}$ ) with the introduction of new native species in degraded stands, were also included. Currently, Greece is addressing the issue of climate change through the National Action Plan, as a sequence of the adaptation of the Directive 2009/28/EC (Article 4) and has submitted to EU, DG-ENERGY, a first version of its national action plan in 2009 and a second version followed in 2011. According to this National Action Plan, a set of measures was taken into consideration. The three starting points of these measures were the establishment of a new Ministry in which climate change is a top priority, the formal acknowledgment of the priority given to achievement of the 2020 targets set (Directive 2009/28/EC and international commitments of the country for the protection of the environment) and the adoption by the Parliament (Law L3851/2010) in which national targets for Renewable Energy sources were specified: $20 \%$ of the total energy consumption, $2 \%$ above the mandatory level of $18 \%$ as they were set by the Directive 2009/28/EC) [30] [31]. Finally, the new Rural Development Program (2014-2020), which is currently on the implementation phase, will take into consideration the forests (production and protection) and forest-related European and National legal obligations.

\section{The National Institutional Framework (Legislation) and Strategic Targets for Biodiversity in Greece}

The National institutional framework for implementation of forest policy in relation to ecosystem protection and conservation of national biodiversity (for different biodiversity issues) is briefly presented in the following table (Table 3 ) [30] [31].

However, apart from the legislation, there is a need for policy initiatives towards adopting different forms of participation. Stakeholders and local communities should be trained to interact. Management bodies/agencies should be supported with experienced staff as well as involving public participation combined with scientific input [6] [23]. Furthermore, recently, the following strategic targets (Table 4) for conservation of biodiversity (future strategy for biodiversity up to 2050) have been set and adopted in Greece [30] [31]. 
Table 3. The national institutional framework for implementation of forest policy in relation to ecosystem protection and conservation of national biodiversity.

\begin{tabular}{|c|c|}
\hline $\begin{array}{l}\text { National institutional } \\
\text { framework }\end{array}$ & Topic \\
\hline Law $1469 / 1950$ & Historical sites and sites of specific natural beauty \\
\hline Law 998/1979 & Protection of Forests \\
\hline Law $1650 / 1986$ & Protection of the Environment \\
\hline Law 204/1994 & Convention for the biological diversity \\
\hline Law $2637 / 1998$ & Refuges of wild life \\
\hline Law 2742/1999 & $\begin{array}{l}\text { Land-Planning and Sustainable } \\
\text { Development and other provisions }\end{array}$ \\
\hline Law 3044/2002 & $\begin{array}{l}\text { Setting up of Management Bodies for } \\
\text { Natural Protected Areas }\end{array}$ \\
\hline Law 3937/2010 & $\begin{array}{l}\text { Framework for the creation and functioning of } \\
\text { management bodies of protected areas }\end{array}$ \\
\hline Law 3937/2011 & Conservation of biodiversity and other provisions \\
\hline State Resolution $80 / 40 / 1990$ & Protection of plant genetic resources of the country \\
\hline State Resolution 67/1981 & Protection of native flora and the wild fauna \\
\hline State Resolution 434/30/1995 & $\begin{array}{l}\text { Conservation and protection of races of local } \\
\text { domestic animals and biotopes of landscapes }\end{array}$ \\
\hline Law 996/1971 & $\begin{array}{l}\text { National Parks, aesthetic forests and nature } \\
\text { monuments under conservation }\end{array}$ \\
\hline Law 191/1974 & $\begin{array}{l}\text { Ratification of Ramsar Convention Protection } \\
\text { of International interest wetlands }\end{array}$ \\
\hline Law 855/1978 - 1634/1984 & $\begin{array}{l}\text { Ratification of Barcelona Convention Protection } \\
\text { of Mediterranean Sea from pollution }\end{array}$ \\
\hline Law $1335 / 1983$ & $\begin{array}{l}\text { Ratification of Bern Convention, Conservation of } \\
\text { wild life and natural environment in Europe }\end{array}$ \\
\hline Law 2719/1999 & $\begin{array}{l}\text { Ratification of Bonn Convention, Conservation } \\
\text { of migratory species of wild life }\end{array}$ \\
\hline Law $2971 / 2001$ & Sea-shores and other provisions \\
\hline Law 743/1977 & Protection of marine environment \\
\hline Law $1269 / 1982$ & Prevention of Sea Pollution from ships \\
\hline
\end{tabular}

\section{Conclusions and Future Challenges}

- Research priority areas on biodiversity and challenges for biodiversity research and related policy in Europe and Greece have been summarized. There are several approaches and tools to support forest policy implementation in Europe.

- Greece has been trying to adapt to new International, European and National conditions and policies. New biodiversity legislation has been adopted since 2012 including for the first time forest-specific measures on species and habitats' protection.

- The new Rural Development Program (2014-2020), which is currently on the 
Table 4. Strategic targets for conservation of biodiversity in Greece.

\begin{tabular}{|c|c|}
\hline & Strategic targets for conservation of biodiversity in Greece \\
\hline 1 & Increase a scientific knowledge for the evaluation of the status of Biodiversity \\
\hline 2 & Conservation of Natural Resources and restoring of ecosystems \\
\hline 3 & $\begin{array}{l}\text { Organization and functioning of a National System for Protected } \\
\text { Areas and enhancing of profits from their management }\end{array}$ \\
\hline 4 & Protection and conservation of forest genetic resources \\
\hline 5 & $\begin{array}{l}\text { Recording and prioritarisation of direct pressures and threats } \\
\text { for the conservation of biodiversity }\end{array}$ \\
\hline 6 & Reasons responsible for the loss of biodiversity \\
\hline 7 & Enhancing of Synergy Politics with the conservation of biodiversity \\
\hline 8 & Conservation of landscape diversity (forest, agricultural, mixed) \\
\hline 9 & Prevention and reducing the impacts on Biodiversity due to climate change \\
\hline 10 & Protection of Biodiversity from invasive alien species \\
\hline 11 & $\begin{array}{l}\text { Enhancing of International and Bilateral cooperation for the } \\
\text { for the protection of Biodiversity }\end{array}$ \\
\hline 12 & $\begin{array}{l}\text { Improvement of the quality and effectiveness of the Public administration in relation to } \\
\text { the protection of Biodiversity }\end{array}$ \\
\hline 13 & Incorporation of conservation of biodiversity into the values system of the society \\
\hline 14 & Participation of the society in the conservation of biodiversity \\
\hline 15 & Assessment of ecosystem services and projection of the value of biodiversity in Greece \\
\hline
\end{tabular}

phase of implementation, will take into consideration the forest itself and forest-related European and National legal obligations.

- In the future, it is critical to identify the linkage between biodiversity, climate change and ecosystem services.

- The main challenges for biodiversity policy are also summarized: a) coding and revising/improving the legislation for the conservation of biodiversity, b) strengthening of the public administration for the implementation and the coordination of political measures and legislation for biodiversity, c) development of forest maps and forest inventory, completion of soil and land use maps for Greece, and d) institutional safeguarding of Natura 2000 areas.

- The future strategy for biodiversity up to 2050 will focus on prevention of destructive changes due to the loss of biodiversity (e.g. total species, keystone species, rare species, indicator species). More specifically, the following issues on biodiversity of Greece were synoptically presented and described: a) strategic targets for biodiversity, b) the pressures and threats on biodiversity in Greece, c) the National institutional framework for biodiversity, d) administration of Natural protected areas and landscapes, and e) the main future challenges.

\section{References}

[1] Convention on Biological Diversity (CBD) (1992) https://www.cbd.int/convention/ 
[2] Secretariat of the Convention on Biological Diversity (2014) Global Biodiversity Outlook 4. Montreal, Secretariat of the Convention on Biological Diversity, 155 p.

[3] CBD (2015) Biodiversity and the 2030 Agenda for Sustainable Development, UNEP Convention for the Biological Diversity.

[4] Larson, T.B., Ed. (2001). Biodiversity Evaluation Tools for European Forests. Ecological Bulletins No. 50. Wallin \& Dalholm, Lund, Sweden, 233.

[5] Hassan, R., Scholes, R. and Ash, N., Eds. (2005) Ecosystems and Human Well-Being: Current Stateand Trends, Volume 1. Millennium Ecosystem Assessment. Island Press, Washington, 913.

[6] Brody, S.D. (2003) Measuring the Effects of Stakeholder Participation on the Quality of Local Plans Based on the Principles of Collaborative Ecosystem Management. Journal of Planning Education and Research, 22, 407-419. https://doi.org/10.1177/0739456X03022004007

[7] Balvanera, P., Pfisterer, A.B., Buchmann, N., He, J.S., Nakashizuka, T., Raffaelli, D. and Schmid, B. (2006) Quantifying the Evidence for Biodiversity Effects on Ecosystem Functioning and Services. Ecology Letters, 9, 1146-1156. https://doi.org/10.1111/j.1461-0248.2006.00963.x

[8] Hautier, Y., Niklaus, P.A. and Hector, A. (2009) Competition for Light Causes Plant Biodiversity Loss After Eutrophication. Science, 324, 636-638.

https://doi.org/10.1126/science.1169640

[9] Spanos, K.A., Feest, A. and Petrakis, P. (2009) Improving the Assessment and Monitoring of Forest Biodiversity. Management of Environmental Quality, 20, 52-63. https://doi.org/10.1108/14777830910922442

[10] Feest, A. (2006) Establishing Baseline Indices for the Quality of Biodiversity of Restored Habitats Using a Standardized Sampling Process. Restoration Ecology, 14, 112-122. https://doi.org/10.1111/j.1526-100X.2006.00112.x

[11] Feest, A., Aldred, T.D. and Jedamzik, K. (2010) Biodiversity Quality: A Paradigm for Biodiversity. Ecological Indicators, 10, 1077-1082.

https://doi.org/10.1016/j.ecolind.2010.04.002

[12] Business and Biodiversity Offsets Programme (2009) Biodiversity Offsets and Stakeholder Participation: A BBOP Resource Paper. BBOP, Washington DC.

[13] Harrison, P.A., Berry, P.M., Simpson, G., Haslett, J.R., Blicharska, M., Bucur, M., et al. (2014) Linkages between Biodiversity Attributes and Ecosystem Services: A Systematic Review. Ecosystem Services, 9, 191-203. https://doi.org/10.1016/j.ecoser.2014.05.006

[14] Herder, D.M., Khadka, C., Pelli, P., Wolfslehner, B., Sandker, M., Lindner, M.,

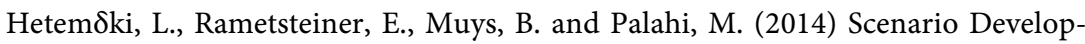
ment to Strengthen National Forest Policies and Programmes: A Review of Future-Oriented Tools and Approaches That Support Policy-Making. Working Paper No. 34, Forestry Policy and Institutions, FAO, Rome.

[15] Spanos, K.A. and Feest, A. (2007) A Review of the Assessment of Biodiversity in Forest Ecosystems. Management of Environmental Quality. An International Journal, 18, 475-486. https://doi.org/10.1108/14777830710753857

[16] Feest, A. and Spanos, K. (2009) An Approach to Measuring Biodiversity and Its Use in Analyzing the Effect of Nitrogen Deposition on Woodland Butterfly Populations in the Netherlands. iForest, 2, 46-48. https://doi.org/10.3832/ifor0487-002

[17] Petrakis, P.V., Spanos, K., Kalapnida, M., Lahlou, E. and Feest, A. (2011) Insect Biodiversity Reduction of Pinewoods in Southern Greece Caused by the Pine Scale (Marchalina hellenica). Forest Systems, 20, 27-41. 
https://doi.org/10.5424/fs/2011201-8924

[18] https://www.ipbes.net

[19] Spanos, K.A., Feest, A., Petrakis, P. and Daskalakou, E. (2010) Salient Points on the Assessment and Monitoring of Biodiversity. Bioremediation, Biodiversity and Bioavailability, 4, 1-7.

[20] De Meester, L., van Tienderen, P., Werger, M., Hectord, A., Wörheide, G., Niemelä, J., Aguilar, A., Smets, E., Godfray, C., Sutherland, W., Bauhus, J., Courchamp, F., Gandini, G., Koch, M., Maho, Y.L., Manuel, M., Pawlowski, J., Quéinnec, E., Owens, I. and Keustermans, L. (2011) Challenges for Biodiversity Research in Europe. Procedia-Social and Behavioral Sciences, 13, 83-100. https://doi.org/10.1016/j.sbspro.2011.03.007

[21] Spanos, K., Grigoriadis, N., Meliadis, I., Gaitanis, D. and Grigoriadis, S. (2012) The Importance and Conservation Values of Beech Forests in Greece-Case Study of an Ancient Beech Forest in the Natura Area "Koula-Haidou" in Xanthi, N. Greece. In: Knapp, H.D. and Fichtner, A., Eds., Beech Forests-Joint Natural Heritage of Europe (2), BfN-Skripten 327, Bonn, 141-163.

[22] Spanos, K.A. (2010) Beech Genetic Resources for Sustainable Forestry in Europe. Proceedings of the Workshop and MC Meeting of the COST Action E52, "Evaluation of Beech Genetic Resources for Sustainable Forestry", Thessaloniki, 5-7 May 2009, 133.

[23] Dafis, S., Papastergiadou, E., Georgiou, K., Babalonas, D., Georgiadis, T., Papageorgiou, M., Lazaridou, T. and Tsiaousi, V. (1997) Directive 92/43/E.C. Works Biotopes in Greece: Network Natura 2000. Gouladri Museum of Natural History-Hellenic Center of Biotopes and Wetlands, EKBY, Thessaloniki, 932. (In Hellenic)

[24] Tsianou, M.A., Mazaris, A.D., Kallimanis, A.S., Deligioridi, P.S.K., Apostolopoulou, E. and Pantis, J.D. (2013) Identifying the Criteria Underlying the Political Decision for the Prioritization of the Greek Natura 2000 Conservation Network. Biological Conservation, 166, 103-110. https://doi.org/10.1016/j.biocon.2013.06.021

[25] Rackham, O. and Moody, J.A. (1996) The Making of the Cretan Landascape. Manchester University Press, Manchester, 237.

[26] Calama, R., Tome, M., Sanchez-Gonzalez, M., Miina, J., Spanos, K.A. and Palahi, M. (2010) Modelling Non-Wood Products in Europe: A Review. Forest Systems, 19, 69-85.

[27] Spanos, K.A., Gaitanis, D. and Spanos, I. (2010) Resin Production in Natural Aleppo Pine Stands in Northern Evia, Greece. Web Ecology, 10, 38-43.

https://doi.org/10.5194/we-10-38-2010

[28] Dimopoulos, P., Raus, T., Bergmeier, E., Constantinidis, T., Iatrou, G., Kokkini, S., Strid, A. and Tzanoudakis, D. (2013) Checklist of the Vascular Plants of Greece. Hellenic Botanical Society (HBS) and the Botanic Garden and Botanical Museum Berlin-Dahlem (BGBM), in press.

[29] Founda, D. and Giannakopoulos, C. (2009) The Exceptionally Hot Summer of 2007 in Athens, Greece-A Typical Summer in the Future Climate? Global and Planetary Change, 67, 227-236. https://doi.org/10.1016/j.gloplacha.2009.03.013

[30] http://www.ypeka.gr/Default.aspx?tabid=237

[31] http://www.minagric.gr/index.php/el/

[32] Fraxigen (2005) Ash Species in Europe: Biological Characteristics and Practical Guidelines for Sustainable Use. University of Oxford, UK.

[33] http://www.ekby.gr/ekby/en/EKBY_Publications_en.html 